\title{
Usoda čustev v zahodni civilizaciji Zdenka Šadl
}

elo, ki ga je avtorica namenila preučevanju čustev iz sociološkega zornega kota $\mathrm{V}$ okviru naše, zahodne civilizacije, je izšlo v zbirki Sophia pri založbi Znanstveno in publicistično središče ob koncu prejšnjega leta.

Avtorica nam v treh temeljnih poglavjih, ki jih spremljata tudi uvodno in sklepno razmišljanje, predstavlja temeljito sociološko študijo o vlogi čustev od najzgodnejših začetkov zahodnega mišljenja, ko so jih še omalovaževali, do današnjih dni, ko so čustva postala središče zanimanja in eno najbolj privlačnih raziskovalnih področij $v$ mnogih znanstvenih disciplinah. Pozornost namenja predvsem preučevanju čustev kot družbenemu konstruktu.

$\mathrm{V}$ prvem delu z naslovom Zahodni konstrukti o čustvih prikaže zgodovino zanimanja za čustva in analizira vrsto filozofskih, teoloških in etičnih teorij ter razlag čustev na podlagi devet mitov oziroma konstruktov o čustvih (konstrukti o čustvih kot neobvladljivih strasteh, o animaličnosti čustev, o čustvih kot fizioloških procesih, o nasprotju med razumom in čustvi, o čustvih kot notranjih in individualnih pojavih, o destruktivnih in nevarnih čustvih, o čustvih kot ženskih lastnostih, o čustvih v sociologiji, krščanski tradiciji in o čustvih v tradiciji slovenskega katolicizma).

Drugi del De-konstrukcija tradicionalnega pojmovanja čustev prikazuje fenomen čustev antropoloških, socioloških). Tezo o družbe-

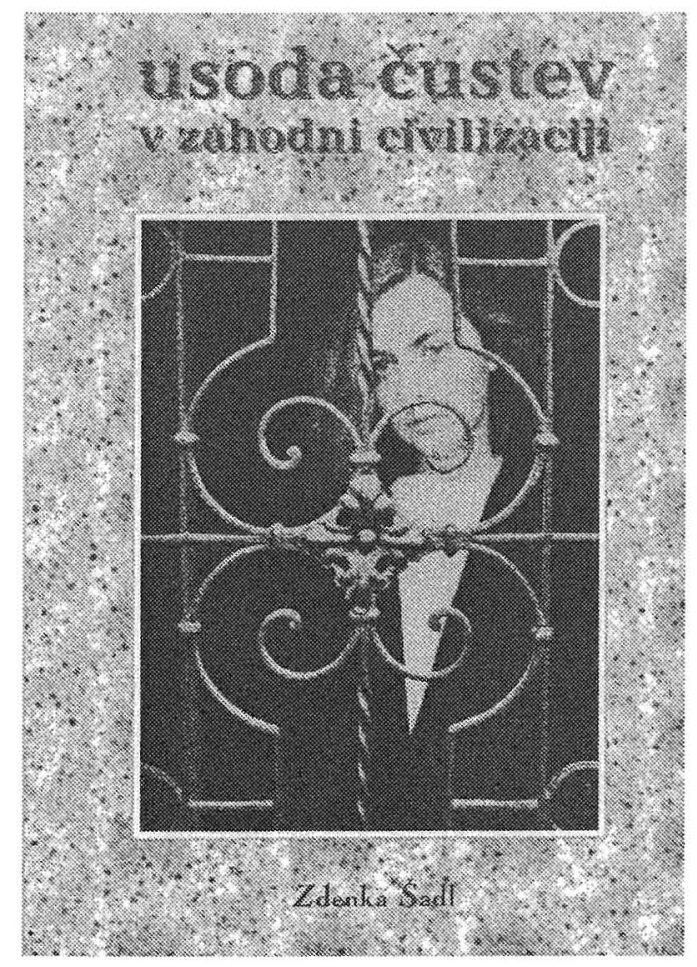

no-kulturni konstituiranosti čustev podpre avtorica $\mathrm{z}$ analizo kulturne in zgodovinske variabilnosti čustev.

V tretjem delu z naslovom Dvojnost sodobne emocionalne kulture: kontrola in de-kontrola čustev avtorica $\mathrm{z}$ analizo življenja $\mathrm{v}$ zelo razvitih sodobnih družbah razvije tezo o osrednji vlogi čustev v teh družbah.

Knjiga je namenjena vsem, ki jih zanimajo stanje sodobne misli in možnosti sodobnega sveta.

Tanja Šulak 